\title{
AN INSIGHT INTO CHANGE MANAGEMENT IN A GLOBAL TRAVEL INDUSTRY
}

\author{
Tri Wulida Afrianty \\ Business Administration Department, Faculty of Administrative Science, Brawijaya University \\ Email: twulidafia@ub.ac.id
}

\begin{abstract}
ABSTRAK
Penelitian ini bertujuan untuk memberikan gambaran secara mendalam tentang strategi yang dilakukan oleh Flight Centre, salah satu perusahaan travel agent global yang terkemuka dalam mengelola perubahan. Secara spesifik, pengelolaan perubahan tersebut meliputi langkah-langkah yang dilakukan oleh Flight Centre untuk memperoleh komiten perubahan dari karyawannya, serta strategi yang dilakukan oleh Flight Centre untuk memanfaatkan budaya perusahaan serta komunikasi di dalam proses perubahan yang dilakukannya. Data utama dalam penelitian ini diperoleh melalui in-depth interview (face-to-face interview dan telephone conversations). Informan penelitian ini berjumlah 14 orang, terdiri dari 4 orang pimpinan Flight Centre (1 area leader dari Victoria and 3 team leaders dari Port Melbourne, Chadstone and Elsternwick stores) dan 10 karyawan Flight Centre dari Port Melbourne, Chadstone, Elsternwick and Brighton. Hasil penelitian ini menunjukkan bahwa Flight Centre merupakan salah satu contoh perusahaan yang berhasil melakukan perubahan dan beradaptasi di dalam industri yang sangat kompetitif dimana banyak perusahaan sejenis tidak mampu bertahan.
\end{abstract}

Kata Kunci: Manajemen Perubahan, Pembelajaran Organisasi, Industri Travel, Australia

\begin{abstract}
This study aims to give an insight into how a global travel agent company, Flight Centre, manages change. Specifically, to gain an understanding as to how and why they make decisions around change, how they gain commitment to change from employees, how they use culture and communication in the change process. The primary data for this research was collected from face-to-face interview and telephone conversations. A total of 4 Flight Centre leaders $(1$ area leader from Victoria and 3 team leaders from Port Melbourne, Chadstone and Elsternwick stores) were interviewed. A total of 10 Flight Centre employees from Port Melbourne, Chadstone, Elsternwick and Brighton were interviewed informally in stores and on the phone. The result shows that Flight Centre is an example of a company that has made change a part of their day-to-day operations and have been very successful in changing and adapting in an industry that has seen a lot of organisations demise.
\end{abstract}

Key words: Change Management, Learning Organisation, Travel Industry, Australia 


\section{INTRODUCTION}

Our era is a period of change that needs to be managed well (Al-Ali, Singh, Al-Nahyan, \& Sohal 2017). Pieterse, Caniëls, and Homan (2012) asserts that to remain competitive, organisations need to continuously adapt to those changes. Moreover, global competition and information technology seem to be the major factors which force organizations to constantly evaluate how they operate in business arena. In doing so, many organizations are utilizing new technologies and managing fundamental changes that have significant implications for their human capital and their management functions (Lawler et al., 2006). Flight Centre, the best known travel agency group in Australia, for example, faces this issue. For the reasons of adapting to changing environment and allowing Flight Centre to maintain its dominant position in the industry, Flight Centre has made change a part of their day-to-day operations and have been very successful in changing and adapting in an industry that has seen a lot of organisations demise.

Flight Centre Limited is the best known travel agency group in Australia, with over fifteen hundred shops, in nine countries and employing over eight thousand employees. The Flight Centre (FC) retail brand is Flight Centre Limited's most successful business. The company was founded in Sydney, Australia in 1981 and therefore a relatively young organisation. The founders, Graham "Skroo" Turner and Geoff Lomas, entered the travel industry when they bought an ageing bus in London and started taking bus tours around Europe. This entrepreneurial and "outside the box" business style has stayed with them throughout their careers and is evident in Flight Centre's philosophies.

This study aims to give an insight into how the organisation Flight Centre implements change. Specifically, to gain an understanding as to how and why they make decisions around change implementation and strategy, how they gain commitment to change from employees, how they use culture and communication in the change process and why they have been so successful at adapting to the environment.

\section{LITERATURE REVIEW \\ Readiness for Change}

Armenakis et al. (1993), theoretically expresses the concept of readiness for change as the perception of employees toward change and their attitudes, behaviors and intentions regarding the prospective change. Further, Armenakis et al. (1993) differentiates the concepts of readiness for change and resistance to change in an organizational context. Specifically, they highlighted the importance of readiness for change to cope up with the problems of resistance to change. Despite its importance, readiness for change is not easy for organizations (Brown and Cregan, 2008), Likewise, it becomes a very complicated task in the current dynamic era when change is going to take place at almost every moment (Jones et al., 2005). When we are concerned with readiness for change, then, it is worth mentioning here that this phase is contextual, it is different from business to business and from industry to industry (Adil, 2016). The time span of readiness for change phase for each organization will depends on the volatility of its business environment, the more volatile a business the lesser the time needed for readiness for change phase and vice versa. If readiness for change phase is truly organized, it will definitely lead to a successful change implementation (Imran et.al, 2017)

\section{Resistance to Change}

It widely believed that resistance is the major impedement to a change. The term resistance to change was first used by Kurt Lewin (1947) as a systems concept, which means resistance found in a system can affect the whole organization - managers and employees as well as other roles in an organization. Resistance to change is generally perceived in the conventional change literature as "collateral damage" of change endeavours. Resistance may have many different presences, varying from foot-dragging, withdrawal, whistleblowingto strike as well as material. As organisational change is considered of as desirable and inevitable, thus people resisting it are framed as irrational Pieterse, Caniëls, and Homan (2012). Consequently, resistance should be managed and overcome properly. 


\section{RESEARCH METHOD \\ Research Type}

Related to the purpose of the research, a descriptive study was conducted. According to Cooper and Schindler (2003), descriptive study is concerned with finding out who, what, where, when, or how of a topic.

\section{Method of Data Collection}

The primary data was collected from in-depth interview and telephone conversations, while the secondary data was mainly gathered from the company's website. For the purpose of interview, some questions were developed as follows:

1. What are the changes that you have seen in the organisation and when was this?

2. What initiated the change?

3. How did you feel before, during and after the change?

4. Who do you think benefited/ was disadvantaged by the change?

5. What was your role in the change effort? Were you involved in making decisions about or influencing the change?

6. Were you expectations about the change effort met?

7. What were the biggest obstacles to implementing the change?

8. How do you measure the effectiveness of the change?

9. How was the change communicated?

\section{Research Participants/ Informants}

A total of 4 Flight Centre leaders ( 1 area leader from Victoria and 3 team leaders from Port Melbourne, Chadstone and Elsternwick stores) were interviewed.

A total of 10 Flight Centre employees from Port Melbourne, Chadstone, Elsternwick and Brighton were interviewed informally in stores and on the phone.

\section{Assumption}

For the purpose of the study, we assume that every Flight Centre store in every area has the same procedures in doing their jobs.

\section{RESULTS AND DISCUSSION \\ Results}

Fierce competition in travel industry compels Flight Centre to adapt to their dynamic environment. Firstly, the tourism industry is diversified and changes all of the time. Seasonality with its associated problems of underutilization of resources and environmental damage causes major difficulties for the travel industry (Costa, 1995). Secondly, according to Kirby \& Jones (2004), in the wake of plunging share prices, airline collapses and global security threats over the past few years, the travel industry is not as flourishing as the past. Tragedies such as 9/11, the Bali bombings and SARS all resulted in fear of travel and the downfall of an increasing number of travel companies. Thirdly, as far as the spread of internet among travel agencies is concerned, the results of previous studies have emphasised the importance of the internet on travel and tourism. The internet provides a way for tourism suppliers to sell their products to potential travellers globally (Law, 2000). At the same time, the internet allows travellers to communicate directly with tourism suppliers to request information, and to purchase products/services at any time and any place (Olmeda \& Sheldon, 2001). Furthermore, large numbers of studies show that at present, tourists can receive comprehensive, timely and relevant information to make their own decision about travel because of the emergence and development of new technologies, such as internet (Leung, Law \& Wong, 2004; Barnett \& Standing, 2001). In addition, nowadays, customers are much better informed about travelling. An increase in customer knowledge about booking travel, as well as people gaining experience through travelling more, makes customers less dependent on the service provider, which highlights the need for travel agencies to now pay more attention to their service quality (Faché, 2000).

Based on the research, there are four key changes that have been implemented in Flight Centre in the last few years that have been driven by the environment discussed above. These are Sunday/public holiday trading, Reward pass, Full Throttle and Palmy client ownership. All of those changes try to adapt to changing environment and allow Flight 
Centre to maintain its dominant position in the industry.

\section{Sunday/ Public Holiday Trading}

This change was a reaction to the internet and started from December 2004. Top managers in Flight Centre decided that they should provide relative and necessary support and service whenever their customers have want to book travel including Sunday and public holiday to keep up with the development of the internet. However, the way of starting change is top-down and no research before, which resulted in this one receiving high resistance. Traditionally, Sunday and public holiday is a day for family and friends. Most employees do not want to work on these days as they are not paid any more to do so. In addition, Sunday/ public holiday trading make most people feel that they are working all of the time and employees already work considerable hours, with all of the people we interviewed saying that they often worked back until $7 \mathrm{pm}$ or $8 \mathrm{pm}$. Only a few young people do not mind to sacrifice their leisure time to make more money and older employees with families were definitely against this change. Some stores in busy areas like shopping centres implemented this change straight away, while most shops do not operate this change even now with employees continuing to come up with reasons as to why they cannot start trading on these days yet.

\section{Reward pass}

The objective of Reward Pass was to improve customer loyalty. Customers who hold the reward pass card can get relative points after they finish travel in FC and those points can be accumulated as money for future trips. This change sounds pretty good but also failed because of a lack of research, lack of training and communication from top-down. In addition, the reward points were able to be paid as they were taken off the consultants' profit margin. This resulted in high resistance due to the fact that it meant cuts in commission, a drop in figures and reduced efficiency due to the extra time it took to explain the program, issue memberships and follow up on queries. This unsuccessful change reflect on unhappy customers, who do not get useful information about reward pass card from consultants as well as frustrated employees, who do not understand the change and are reluctant to pay for the rewards. FC lost millions of dollars through this failed change and potentially damage to the image of company.

\section{Full Throttle}

The aim of this change is very clear; cost cutting. This change started after the 9/11 terrorist attacks, 2001, which was a hard time for all the travel agencies. Flight Centre also had to reduce costs. This change received resistance at the beginning but still works because of high levels of effective and repeated communication, clear explanations as well as transparency of information. All the levels in Flight Centre utilised their unique imagery, language to explain to their people that it is a tough time for the company and why they need to cut costs and transfer their culture and spirits to inspire their people that they can conquer it. It was evident through the fact that the area leader we interviewed held the area Christmas party at his house, with staff members' friends and family helping out as bar tenders and dj's at the party. This showed that all levels were involved and also had to reduce spending and also provided a great story that will be used in the future to show how the Flight Centre "family" pull together when times are tough.

\section{Palmy}

This change only started a few months ago. It is the biggest change in FC, and includes: new client ownership scheme, new advertising campaign "Unbeatable", self-booking machines in store, and in the future a new look store which is more cohesive to customer service. This change is due to the development of internet, customer knowledge and low retention of new employees. Compared with before, majority of customers have more knowledge and experience about travelling, they do not only need a specific person to book a ticket for them, they have become more and more demanding in wanting more detailed information and add on services. All of these reasons require a change in the core idea of what employees jobs are in FC; they are no longer just a booking agent but a customer service agent. They need to change the role of their work from a booking agency to a service agency. In addition, self-booking machines in store free more consultants to 
provide service to their customers. This is a change of strategic, HRM and techno-structural, with benefits for customers as well as employees and the organisation. For customers, they can attain better services and choose consultant freely; for consultants, they have more time and more interesting work. For the organisation, more competition and pressure on consultants impel the organisation to improve customer service and acquire more competitive strength.

It can be identified that most changes in Flight Centre are incremental, evolutionary changes - except for Palmy which presents a change in the essence of the job role. Related with these changes, basically, the employees' attitude toward the changes is 'just do it'. This maybe because the employees believe that change is a part of the company's way of life. They have a strong view that changes are important, especially being in the travel industry when things change very often. They also believe that if they do not change, they will pretty much not keep up with what is happening and they will not be survive for the long time.

Although the employees have many opportunities to express views, which are part of the regular system, the changes are enforced and directed from the head office in Brisbane. However, Flight Centre usually give flexibility in when the change is implemented - they might set a date in four months time and some stores may change straight away, but if other stores need more time they can take it and adapt to the change. Moreover, Flight Centre sometimes uses a trial system for changes to see how they go in one area before they change the whole company. Afterwards, if the change clearly is not working, the head office will reverse it.

Regardless the 'just do it' attitude of the employees toward the changes, in this study, we have found that resistance to change sometimes happen in the company. For many reasons, the resistance tended to come from employees that have been in the company the longest. Thus, in this study, we view the resistance as a challenge for Flight Centre in implementing the changes. Another challenge that we have identified is the 'just do it' philosophy will getting more costly as the company has grown significantly in the last few years. The reversion of the Reward Pass program, for example, cost the company millions of dollars.

\section{Discussion \\ Communication and Resistance to Change}

As has been identified in the finding section of this report, one of the challenges in implementing the changes in Flight Centre is resistance to change from the employees which can be categorized as a human resource issue. Mainly, the employees resist the change because they perceive the benefits to the organization are not necessarily inline with their interests (like in Reward Pass program). Another reason is the changes often involves more work in the short term and requires learning and adjustments. In regard with this issue, since resistance to change usually goes hand and hand with change itself (Jarret, 2004), instead of viewing the resistance as something negative, it is beneficial for Flight Centre to view this issue as a natural consequence of company's major program which can provides constructive feedback to the change process if it is managed properly.

In order to deal with and manage the resistance, Atkinson (2005, p. 15) suggests that, it is needed to elicit the reason for doing so and carefully list these objections. Then, for every objection that has identified, it is needed to formulate a response to counter it. Furthermore, he asserts that the most important thing in dealing with this issue is not to 'win the war' or argument, but to help others, those who resist the change, to reframe things to see beyond their relatively negative viewpoint. In doing so, it is crucial to establish an effective two-way communication. This is important since one of the sources of resistance to change is communication barriers that lead to information distortion and misinterpretations (Hutt et al., 1995, cited in Pardo del Val \& Fuentes, 2003). Specifically, Elving (2005) argues that resistance to change can be managed by effective communication during organizational change. Thus, in relation with this issue, the Flight Centre leaders in all levels need to 'sell' the benefit that will be gained by the company as a whole (employees and customers are included) due to the change. Moreover, the reasons behind the changes also need to be well communicated to generate a feeling of need for change among employees. This is because 
people only change when they understand why it is important (Preston, 1999). In addition, it is also beneficial for the company leaders to give their support and understanding to the employees during the change process.

Other objections, like there will be new work processes that need to be learnt, could be countered by managing relevant trainings for the employees. As has been advanced by Rusaw (2000, p. 249), training is a form of organizational change which enables employees to do many things such as to demonstrate new concept, build skills, and solve difficult technical problems. For the case of Flight Centre, where there is a need for adjusting to the new work processes, relevant technical skills should be covered in the training. Training may be formal, where employees spend a day in head office learning new skills, or a trainer may visit the stores individually and spend time with employees helping to develop their skills. Training may be as simple as an online training module and test to be completed by employees within a timeframe or a document that is sent to the stores and read by employees in morning meetings. Therefore, Flight Centre utilises many forms of learning to assist employees to cope with and benefit from changes. The inhouse, full time trainers that Flight Centre employs are evidence of their commitment to adequately training employees.

In short, in order to deal with the resistance to change in Flight Centre, two human resource management interventionscommunication and training-development program on individual level and group levelare evident and recommended.

\section{Culture and Change}

It was evident through our research that Flight Centre had a very strong culture and that this affected Flight Centre's ability to adapt and change. Particularly, it affected Flight Centre's ability to gain commitment to change, and ease of implementing the changes. There were a number of elements of their culture that did this and showed the importance of culture to a change effort. Firstly, the influence of a very young workforce was evident, with all of the team leaders remarking that younger employees were less resistant to change. Generation Y workers are said to enjoy change and new experiences as well as the chance to gain new skills to increase their employability, therefore Flight Centre's youthful culture of many social events attracts this type of employee who naturally copes with change more readily (Spencer, 2006).

The emphasis that Flight Centre put on culture fit with employees is also evident through their recruitment and selection process where candidates receive extensive information about the organisation. Extensive information and a "trial day" in a store, enable the future employee to self-select out if the culture does not fit them and for the company to also gain enough information about the candidate to make the best possible decision. Continued socialisation, starting from the information promoted on their recruitment page on their website, through to training updates and events throughout employees careers act to continue to hold the culture tightly together. It is evident that maintaining such a strong culture takes constant attention and there is a price to pay in high turnover rates, however, this may be a necessary part of the process (Zeffane, 1994).

Jick (2001) states that it is a leader's primary responsibility to ensure that the overall culture, including their own behaviour, reinforces and supports their vision and philosophies. It is evident at Flight Centre that when changes work this is the case, proving the fact that changes are a lot easier to get support for when they are in line with the companies core philosophies. In addition, when leader's show behaviours that are consistent with these philosophies they gain credibility and employees are therefore more likely to trust that when changes are implemented they are in the employees' best interests. Errol and Winston (2005) show a strong correlation between leader behaviour and leader trust and organisational trust.

Through a network of artefacts; symbols, stories and ceremonies, the vision and culture are further strengthened. Oztel and Hinz suggest that when changes are occurring leaders or change agents should put more weight on using, for example, stories, images and narratives. This is evident in Flight Centre where language is used very strongly to engage a sense of belongingness and commitment during changes. 
It is evident that an organisations culture's is an important factor in managing change. Carnall (2003) emphasises the difficulty in transforming organisational cultures. Balogun and Hope Hailey (2004, cited in Todnemby, 2005) report that seventy per cent of change initiatives fail. Therefore, it is better to start with an adaptive culture and focus efforts on continually maintaining and strengthening a culture that promotes renewal in line with the external environment. Meyer and Stensaker describe an organisations "capacity to change" as the important factor in today's ever changing environment. Flight Centre's culture encourages a readiness, or capability to change. Flight Centre has this advantage as it is a younger company, which is not "weighed down by historic baggage, but alert to the unknowable future" (Salaman \& Asch, 2002, p. 191).

\section{Learning Organisation}

Flight Centre presented a number of attributes associated with a learning organisation. Casey describes it as a "system's ability to adapt to its environment through performance and learning actions that influence collective cultural values" (2005, p. 138). Learning organisations have been emphasised as the model to best adapt to the ever changing environment that we are currently facing (Garavan, 1997). In order for an organisation to successfully be a "learning organisation" there is a number of features that need to be present. The following discusses the features that were evident at Flight Centre and how they have attributed to their success in being able to adapt.

- Informal communications as well as formal lines are evident. Teams are necessary to facilitate informal communication and diffuse information (Casey, 2005).

- There is a very flat structure and an open door policy that encourages employees at all levels to interact and share information.

- Embedded in the culture is an attitude about coping with change as a continual process (as discussed in section IV, B).

- Flight Centre encourages performing employees to move up in their career quickly and therefore promotes learning by providing associated training and mentoring as they develop. They also invite performing employees to return at any time if they leave the organisation to pursue travel, studies or other positions. This brings more information back into the organisation.

- Flexible work arrangements allow employees to go part time, job share or temp. This assists the company to retain knowledge when employees go back to study or have children or other family commitments (Lee-Kelley, Blackman \& Hurst, 2007).

- Knowledge is diffused throughout the organisation and not kept within "centres of excellence" (Ulrich, Von Glinow \& Jick, 1993, p. 52). Part of the 'Palmy' project was developed as one store took the initiative to change the way consultants "owned" clients in the store and they found it to be successful and has now been implemented across Australia.

- Explicit knowledge is stored in the central intranet and employees have access to majority of the organisational information as well as a wealth of information about how to improve their job and a question and answer mechanism where you can post a question and other staff members in any store can answer your question.

- Sim Sitkin suggests that regular "small failures actually promote learning" (cited in Ulrich et al, 1993, p. 56). At Flight Centre employees are encouraged to attempt things and make mistakes that they learn from. In addition, at an organisational level, as the company implements changes due to foreseen risks, not all changes work. However, when they do not work they learn from them for future changes. Lewin (cited in Schein, 1996) further emphasises the importance of this "just do it" implementation style by suggesting that you cannot understand an organisation until you try to change it. Through Flight Centre's continual intervening they are enabled to gain a better understanding of the system. 
- From the above discussion, many elements of a learning organisation as presented in much of the literature as the ideal way to cope with today's turbulent environment, is evident in Flight Centre. The company's ability to adapt is evident and supports the notion of a learning organisation to effectively deal with change.

\section{CONCLUSIONS AND RECOMMENDATIONS \\ Conclusions}

From this research a number of things become evident. Firstly, that Flight Centre is an example of a company that has made change a part of their day-to-day operations and have been very successful in changing and adapting in an industry that has seen a lot of organisations demise. There are a number of reasons that can be drawn that contribute to their success. Through a strong culture that emphasises the ability to adapt, encourages individual responsibility and a sense of family, they encourage people to trust superiors and commit to changes. They effectively communicate and justify changes through regular (daily, weekly and monthly) forums that also allow for individuals to air their opinions in small groups or on a one-on-one basis and break down resistance to change. They share knowledge, promote and act with egalitarian values, encourage and develop their employees to learn and grow and have a flat structure; all features of a learning organisation. It is also evident that these things require daily maintenance and also that these ideals must be supported in every single part of the system. When a change went against one of Flight Centre's philosophies the change did not work and was met with employee resistance. In addition, it was clear that one of the reasons that Flight Centre was able to so readily adapt and create such a culture was due to the fact that it is a relatively young organisation and that this ability to adapt has been supported and strengthened from the very beginning. While Flight Centre portrays an exemplary example of an organisation that has realised that change is a reality and has developed its system to effectively cope with these changes, there were also some areas which we saw could be further developed. These are listed in the recommendation section of this paper.

\section{Recommendations}

Based on the analysis of what is happening in Flight Centre and the key challenges of the changes the following specific recommendations are therefore made:

- Do more research before suggesting a change as one way to minimize the possibility of the reversion which could cost the company both financially and non financially.

- Only make changes which are consistent with their philosophies.

- Encourage employee participation in the planning and decision making process instead of purely implementing top-down policy.

- Maintain an effective two-way communication/consultative approach among all management levels, instead of enforcing and directing the changes from the head office.

- Conduct training-development program both on individual and group levels to help the employees for adjusting to the new work processes

\section{Limitations}

The research sample is small and therefore it is difficult for conclusions drawn to be generalised. In addition, as it still requires the researcher interpretation of what both employees and team leaders say, the result of this research could be subjective.

\section{References}

Al-Ali, A. A, Singh, S. K., Al-Nahyan, M., Sohal, A.S. (2017) "Change management through leadership: the mediating role of organizational culture",International Journal of Organizational Analysis, Vol. 25 Issue: 4, pp.723-739, https://doi.org/10.1108/IJOA-01-20171117

Appelbaum, S., St-Pierre, N., Glavas, W. (1998), "Strategic organizational change: the role of leadership, learning, motivation and productivity", 
Management Decision, Vol. 36, No. 5, pp. 289-301.

Atkinson, P. (2005), "Managing resistance to change", Management Services, Vol. 49, No. 1, pp.14-19.

Barnett, M., Standing, C. (2001), "Repositioning travel agencies on the Internet", Journal of Vacation Marketing, Vol. 7 No.2, pp.143-52

Carnall, C. (2003), Transformation perspective in "Managing change in organizations", Prentice Hall, pp. 1137.

Casey, A. (2005), "Enhancing Individual and Organizational Learning: A Sociological Model", Management Learning, Vol. 36, No. 2, pp. 131-147.

Cooper, D. R., \& Schindler, P.S. 2003. Business research methods ( $8^{\text {th }}$ edition). New York: McGraw-Hill.

Costa, J., (1995), "International perspectives on travel and tourism development", International Journal of Contemporary Hospitality Management, Vol. 7 No. 7, pp. 10-19

Diefenbach, T. (2007), "The managerialistic ideology of organizational change management", Journal of Organizational Change Management, Vol. 20, No. 1, pp. 126-144.

Elving, W. J.L. (2005), "The role of communication in organisational change ", Corporate Communications: An International Journal, Vol. 10, No. 2, pp. 129-138.

Faché, W., (2000), "Methodologies for innovation and improvement of services in tourism", Managing Service Quality, Vol.10 No.6, pp. 356-366

Gotwon, G. and Ditomaso, N. (1992), "Predicting Corporate Performance from Organizational Culture", Journal of Management Studies, Vol. 29, No. 6, pp. 783-799.
Garavan, T. (1997), "The learning organization: a review and evaluation", The Learning Organization, Vol. 4, No. 1, pp. 18-29.

Jarrett, M. (2004), "Tuning into the emotional drama of change: extending the consultant's bandwidth", Journal of Change Management, Vol. 4, No. 3, pp.247-258.

Jick, T. (2001), "Vision is 10\%, Implementation the Rest", Business Strategy Review, Vol. 12, No. 4, pp. 36-39.

Kirby, A. \& Jones, K. (2004), "Family fortunes at Flight Centre: unusual business model takes off for award-winning travel agency", Human Resource Management International Digest, Vol. 12 No. 6, pp.33-34.

Lawler, E. E., Boudreau, J. W., Mohrman, S. A., Mark, A. Y., Neilson, B., \& Osganian, N. (2006), Achieving strategic excellence: an assessment of human resource organizations, Stanford University Press, California.

Lee-Kelley, L., Blackman, D. and Hurst, J. (2007), "An exploration of the relationship between learning organisations and the retention of knowledge workers", The Learning Organization, Vol. 14, No. 3, pp. 204221.

Leung, K., Law, R., \& Wong, R, (2004), “The impact of the Internet on travel agencies", International Journal of Contemporary Hospitality Management, Vol.16 No. 2. pp. 100107.

Mento, A., Jones, R. and Dirndorfer, W. (2002), "A change management process: Grounded in both theory and practice", Journal of Change Management, Vol. 3, No. 1, pp. 45-59.

Meyer, C., Stensaker, I. (2006), "Developing Capacity for Change", Journal of Change Management, Vol. 6, No. 2, pp. 217-231.

Oztel, H. and Hinz, O. (2001), "Changing organisations with metaphors", The 
Learning Organization, Vol. 8, No. 4, pp. 153-168.

Olmeda, I., Sheldon, P. (2001), "Data mining techniques and applications for tourism Internet marketing", Journal of Travel \& Tourism Marketing, Vol. 11 No.23,pp.1-20.

Pardo del Val, M., \& Fuentes, C. M. (2003), "Resistance to change: a literature review and empirical study", Management Decision, Vol. 41, No. 2, pp. 148-155.

Jos H. Pieterse, Marjolein C.J. Caniëls, Thijs Homan, (2012),"Professional discourses and resistance to change", Journal of Organizational Change Management, Vol. 25 Iss: 6 pp. $798-$ 818

Preston, D. R. (1999), “Organizational aikido: implementing change without a fight", Journal for Quality \& Participation, Vol. 22, No. 5, pp. 24-26.

Rusaw, A. C. (2000), "Uncovering training resistance: a critical theory perspective", Journal of Organizational Change, Vol. 13, No. 3, pp. 249-263.

Salaman, G., Asch, D. (2002), "Improving organisational performance", European Business Journal, Vol. 14, No. 4, pp.186-192.

Schein, E. (1996), “Kurt Lewin's Change Theory in the Field and in the Classroom: Notes Toward a Model of Managed Learning", Systems Practice, Vol. 9, No. 1, pp. 27-47.

Sorensen, J. (2002), "The Strength of Corporate Culture and the Reliability of Firm Performance", Administrative Science Quarterly, Vol. 47, No. 1, pp. 70-91.

Spector, J. and Davidsen, P. (2006), "How can organizational learning be modelled and measured?", Evaluation and Program Planning, Vol. 29, pp. 63-69.

Spencer, P. (2006), "Always on the move", Travel Weekly Australia, Vol. July, p. 27.
Sterman, J. (1994), "Learning In and About Complex Systems", System Dynamics Review, Vol. 10, Nos. 2-3, pp. 291-330.

Todnemby, R. (2005), “Organisational Change Management: A Critical Review", Journal of Change Management, Vol. 5, No. 4, pp. 369-380.

Ulrich, D., Von Glinow, M. and Jick, T. (1993), "High-Impact Learning: Building and Diffusing Learning Capability", Organizational Dynamics, Vol. 22, No. 2, pp. 52-66.

Zeffane, R. (1994), “Understanding Employee Turnover: The Need for a Contingency Approach", International Journal of Manpower, Vol. 15, No. 9, pp. 22-37. 